\title{
Putting the puzzle together: apparel professionals' perspectives on creativity
}

\section{By: Elena Karpova, Sara Marcketti \& Jessica Barker}

This is an Accepted Manuscript version of the following article, accepted for publication in International Journal of Fashion Design, Technology, and Education.

Karpova, E., Marcketti, S., \& Barker, J. (2011). Putting the puzzle together: Apparel professionals' perspectives on creativity. International Journal of Fashion Design, Technology, and Education, 4(2), 103-113.

It is deposited under the terms of the Creative Commons Attribution-NonCommercial-NoDerivatives License (http://creativecommons.org/licenses/by-nc-nd/4.0/), which permits non-commercial re-use, distribution, and reproduction in any medium, provided the original work is properly cited, and is not altered, transformed, or built upon in any way.

\begin{abstract}
:
The purpose of this study was to understand the role of creativity within the apparel industry by exploring experiences and perspectives of industry professionals. This research investigated: (1) how the industry insiders understood creativity and (2) how they utilised it in their careers. In-depth, structured interviews were used to collect the data. A total of 28 professionals in diverse positions employed in various apparel-related organisations participated in the study. A phenomenological interpretation of the data resulted in three topical areas that allowed mapping the creativity phenomenon to facilitate a deeper understanding of its nature, manifestation and outcomes. The mapping process resulted in a creativity framework that may be used for developing creative thinking skills and opens up new research venues.
\end{abstract}

Keywords: creativity | apparel industry | interview

\section{Article:}

\section{Introduction}

Innovation is essential to a company's success and sustained competitive advantage, and employees' creativity provides for such innovation (Ford and Gioia 2000). Despite the wide recognition of the importance of creativity to organisational success, there is little consensus on what constitutes creativity and how it is utilised in the workforce. For example, a creativity expert noted that it 'can be regarded as the quality of products or responses judged to be creative 
by appropriate observers, and it can also be regarded as the process by which something so judged is produced' (Amabile 1983, p. 359). Other definitions of creativity encompass the creative person and the creative environment (Warr and O'Neill 2005).

The importance of creativity in the fast-paced and extremely competitive apparel business is undeniable (Malem 2008). The apparel industry is characterised by shortened product life cycle and increased globalisation. It is within this environment that the importance of creativity comes to the forefront if companies are to compete, thrive and lead (Gumusluoglu and Ilsev 2009). Despite the critical role of creativity in the apparel business, researchers have not yet examined industry professionals' views on this topic. The purpose of this study was to understand the creativity phenomenon within the apparel field by exploring experiences and perspectives of apparel professionals. This research investigated: (1) how the apparel industry insiders understood and defined creativity and (2) how they utilised it in their careers. This study examined whether apparel professionals in diverse positions and responsibilities held different perceptions of creativity and its role in their day-to-day responsibilities. Such exploration allowed for understanding the meaning and role of creativity in professions associated with apparel and fashion. Educators can then use this knowledge in efforts to develop and enhance student creativity.

\section{Literature review}

\subsection{Creativity}

Definitions of creativity have evolved over several decades and have encompassed the concepts of the creative process, person, product and environment (Warr and O' Neill 2005). While definitions of creativity are elusive, consistent concepts appear across most characterisations; in that, creativity is a topic of wide scope that is important at both the individual and at the societal level (Sternberg and Lubart 1999). The multi-dimensional nature of creativity, encompassing individual traits and behaviours as well as the interaction between creative individuals, their ideas and society, makes it particularly difficult to capture and measure (Runco 2004). According to Pedersen and Burton (2009), 'The components of creativity are used in such diverse ways that developing a single definition of the concept is not possible' (p. 15). Creativity is generally conceived as the ability to produce work that is both novel (i.e. original) and appropriate (i.e. useful and valuable) (Sternberg and Lubart 1999). It is a complex phenomenon studied from the diverse perspectives of business, cognitive science, philosophy, psychology, sociology, anthropology and religion, among others.

\subsection{The creative individual}

The lives of creative individuals are important to study because the results of their work enrich the culture and economy, positively impacting and improving society's quality of life 
(Csikszentmihalyi 1990). Human creative potential is a virtually limitless resource that defies racial, social, economic and gender categorisation (Florida 2002). It is generally accepted that there needs to exist a modicum of intelligence for an individual to exhibit creativity (Furnham and Bachtiar 2008). Csikszentmihalyi (1990) argued convincingly that individual creativity cannot exist unless there is a respective domain and field.

The defining characteristic of creative people is that they engage in complex problem solving to find innovative and valuable solutions (Florida 2002). While it is possible to make a creative discovery by accident or without much interest in a particular topic, most creative contributions are made by individuals with great interest, passion and knowledge within a specific field (Csikszentmihalyi 1990). Researchers contend that creativity exists along a continuum, with creative outputs ranging from minor adaptations to significant, life-altering breakthroughs (Shalley et al. 2000). Creativity should not be reserved for professionals working in artistic fields such as dance or product development, but can be present in any occupation (Kaufman and Beghetto 2008). As stated in Fiore (2008), creative potential transcends job titles such as designer, artist and musician to include scholars, scientists and entrepreneurs. While personality traits such as extroversion may or may not predict creative behaviours, several studies have attributed openness to new experiences as a great advantage for recognising potential novelties in one's domain (Furnham and Bachtiar 2008).

In one study of doctoral students in the fields of health, biology and social sciences, differences were found with regard to the effectiveness with which individuals working in that discipline executed creativity-related skills (Mumford et al. 2010). The authors suggested that the presentation of these skills was related to the demands of the specific occupation. Most creativity experts agree that creative process is dependent on the specific field (Csikszentmihalyi 1990) and question whether a general creative process model can be applicable across different domains (Lubart 2001). This trend in the creativity literature calls for exploration of creative processes within specific domains, e.g. the apparel profession.

\subsection{Creativity in the apparel profession}

According to Dohr (1982), as cited in Pedersen and Burton (2009), creativity is 'one of the key competencies required by entering [interior design] professionals' (p. 21). Within the apparel field, there have been a limited number of studies on creativity. Danielson (1986) surveyed 55 major contemporary fashion illustrators to provide insight into their creative processes to enrich classroom teaching on the subject. Cerny et al. (1993) found outcomes of belonging to a guild extended beyond learning the craft of quilt-making to the empowerment of individual and group creativity. In a review of aesthetics literature on the creative process, Fiore et al. (1996) concluded with a call 'for researchers to interpret the introspective thoughts of the creator' (p. 38). At the 2008 Apparel Executive Forum keynote presentation, Patty Devlin of Play, a consulting company, urged designers to 'seek a diversity of inspiration' by incorporating different perspectives in the workplace, become comfortable with ambiguity, and promote 
risk-taking or 'passion in action', key aspects identified in the literature for enhancing creativity (Speer 2008). A recent qualitative investigation that explored 'business techniques and survival strategies of British fashion designers' advocated for the need of research on innovation in the creative industries (Malem 2008, p. 398). Csikszentmihalyi (1990) argued that depending on the researchers' domain, the creativity phenomenon is referred to as innovation in sociology, entrepreneurship in business and economics and other terms are used in history and literature.

\subsection{Theoretical perspectives on creativity}

Researchers have developed various approaches to conceptualising creativity and theorising about the phenomenon. The psychological branch of creativity research tends to focus on the individual and his personality, values, as well as intrinsic and extrinsic motivations. Indeed, multitude research studies demonstrated that creative people have certain personality attributes such as self-efficacy, willingness to overcome obstacles, risk-taking and tolerating ambiguity and uncertainty (Sternberg 2006). Amabile's (1983) componential model accounts for differences in the level of creative productions through individual differences in task motivation. A shortcoming of this research stream is that it often reduces 'creativity to traits [inherited or learned] and genes' (Goswami 1996, p. 47).

Other scholars have investigated how differences in cognitive processes might help to explain creative performance. Milgram (1990) argued that creative thinkers are capable of (1) perceiving and defining problems differently, (2) noticing things that others ignore and (3) storing and retrieving information in their own way. Additional cognitive skills associated with creativity include the synthetic skill of seeing problems in new ways, the analytic skill for evaluation of proposed ideas and the practical skill of selling your ideas to other people (Sternberg 2006). Mumford (2003) noted that opportunity recognition, or the identification of existing problems in the market place, and idea generation, or the creation of multiple possible solutions for a problem, are two of the most important factors for creative performance.

Sociologists have primarily focused on the environment and its influence on creativity and the creative individual. Sternberg (2006) argued that '[o]ne could have all of the internal resources needed to think creatively, but without some environmental support (such as a forum for proposing those ideas), the creativity that a person has within him or her might never be displayed' (p. 89). Another stream of creativity research focuses on assessing creative outcomes from a socio-psychological perspective - artworks, ideas and solutions to various problems (Amabile 1983, Csikszentmihalyi 1990).

In recent years, a more holistic approach to the study of creativity has become a noticeable trend. This approach incorporates 'environmental perspectives with more traditional trait- and process-oriented perspectives' (Harrington 1990, p. 164). For example, the investment theory postulated that six distinct resources are required for creativity, including intellectual abilities, knowledge, styles of thinking, personality, motivation and environment (Sternberg 2006). A number of models have been developed to explain the creative process in various fields 
such as art (Sapp 1995), science (Busse and Mansfield 1980) and acting (Nemiro 1997). Even though some of the stages of the creative process are the same across different fields (e.g. idea generation and idea evaluation), others are different. For example, problem finding in art is internally oriented (Dudek and Côté 1994), while in science it is an externally oriented process (Ochse 1990). Despite many advances in the creativity research, a unifying theory or framework has yet to be proposed (Gluck et al. 2002). One of the reasons could be the 'variability in the nature of creative behaviour' across different occupations (Mumford and Gustafson 1988, p. 28). Therefore, it is important to explore the phenomenon of creativity within the context of apparel profession.

\section{Method}

To explore apparel professionals' perspectives of creativity, a qualitative methodology was selected to obtain 'rich' or 'thick' data (Kvale 1996, Esterberg 2002). This type of data allowed for a deeper understanding of the creativity phenomenon through participants' descriptions of everyday experiences (van Manen 1990). Individual, semi-structured interviews were utilised to collect the data. This approach allowed participants the opportunity to explore the topic of creativity in their own words by freely expressing ideas and opinions. At the same time, following an interview protocol ensured a systematic approach to data collection and minimised interviewer bias (Kvale 1996). Examples of questions included: 'What set of skills does your position require?', 'Why are these skills important?', 'What does creativity mean to you?', and 'How is creativity demonstrated in the industry?'

A purposive, snowball sampling technique maximised the acquisition of relevant information (Esterberg 2002). Upon gaining institutional review board approval, the authors contacted members of a Midwestern university's textiles and apparel programme advisory board to invite them to participate in the study. Each interviewee was asked to recommend other potential research participants. Approximately half of the interviews were conducted in person, with the remainder completed over the telephone because of geographical restraints. With informants' consent, all interviews were audio taped and transcribed to ensure accuracy in data analysis. Interviews ranged from 1 to 2 hours in length.

A total of 28 professionals were interviewed (Table 1). We ensured representation of employees from small-, medium-, and large-size firms as well as a mix of diverse job titles and responsibilities, including designers (nine), product developers (three), merchandisers (four), sales managers (three), entrepreneurs (four), educators (three) and museum curators (two). Six participants in the final sample were members of the programme's advisory board. Eighteen of the 28 professionals were alumni of the university's textile and apparel programme. Participants represented a wide range of companies located throughout the USA, from mass market and specialty retailers to manufacturers and apparel import intermediaries to designer's houses. Participants' work experience ranged from 2 to 30 years. The majority of the participants were 
female, while five (18\%) professionals were male. To ensure confidentiality, no companies' names were used, and each informant was assigned a pseudonym in the data analysis process.

A phenomenological interpretive approach was used to analyse the transcribed interviews. This interpretation of the data resulted in the emergence of significant themes that described participants' experiences and perceptions related to creativity and its role in the apparel industry (van Manen 1990). Interview transcripts were first analysed by the three authors independently through an iterative part-to-whole process (McCracken 1988, Spiggle 1994). Next, the researchers worked together to compare, discuss, critically evaluate and finalise emergent themes into a consistent whole utilising a back-and-forth, part-to-whole process of interpretation (Spiggle 1994). The major themes formed three topical areas. The first topical area, creative thinking strategies, summarised participants' opinions on creativity in the context of apparel profession. The second topical area, manifestation of creative thinking, described how creativity was realised in the apparel industry. Professionals' perspectives on the purposes of creativity formed the last topical area, creative outcomes.

Table 1. Description of participants

\begin{tabular}{|l|l|l|l|l|l|}
\hline Name & Gender & $\begin{array}{l}\text { Years of } \\
\text { experience }\end{array}$ & Job title & Company description & $\begin{array}{l}\text { Company } \\
\text { location }\end{array}$ \\
\hline Abby & Female & 5 & $\begin{array}{l}\text { Interactive } \\
\text { coordinator }\end{array}$ & Self-employed & Northeast \\
\hline Alice & Female & 2 & $\begin{array}{l}\text { Senior business } \\
\text { analyst }\end{array}$ & Mass market retailer & Midwest \\
\hline Amber & Female & 5 & Associate designer & $\begin{array}{l}\text { Product } \\
\text { developer/importer }\end{array}$ & Midwest \\
\hline Bob & Male & 5 & Associate designer & Specialty retailer & Northeast \\
\hline Clara & Female & 26 & Educator & University & Midwest \\
\hline David & Male & 5 & Freelance designer & Self-employed & Northeast \\
\hline Don & Male & 28 & VP, sales & Importer & Northeast \\
\hline Jennifer & Female & 7 & $\begin{array}{l}\text { Freelance } \\
\text { consultant }\end{array}$ & Self-employed & Northeast \\
\hline Elizabeth & Female & 4 & Associate designer & Specialty retailer & Northeast \\
\hline Ella & Female & 7 & Designer & Specialty retailer & Northeast \\
\hline Emma & Female & 14 & $\begin{array}{l}\text { VP, technical } \\
\text { design }\end{array}$ & Designer's house & \\
\hline
\end{tabular}




\begin{tabular}{|l|l|l|l|l|l|}
\hline James & Male & 30 & Creative director & Manufacturer/importer & Northeast \\
\hline Jess & Female & 9 & Designer & Self-employed & Midwest \\
\hline Julia & Female & 32 & Educator & University & Midwest \\
\hline Helen & Female & 9 & Sales manager & Designer's house & Northeast \\
\hline Kelly & Female & 31 & Educator & University & Midwest \\
\hline Kris & Female & 9 & $\begin{array}{l}\text { Manager, product } \\
\text { development }\end{array}$ & Designer's house & Northeast \\
\hline Kyla & Female & 23 & $\begin{array}{l}\text { Director, product } \\
\text { development }\end{array}$ & $\begin{array}{l}\text { Private label } \\
\text { developer/importer }\end{array}$ & Southeast \\
\hline Lana & Female & 25 & $\begin{array}{l}\text { Chief officer, } \\
\text { merchandising }\end{array}$ & Manufacturer/importer & Northeast \\
\hline Leigh & Female & 11 & $\begin{array}{l}\text { Period clothing } \\
\text { supervisor }\end{array}$ & Museum & Midwest \\
\hline Linda & Female & 17 & Textile curator & Museum & Midwest \\
\hline Lynn & Female & 25 & VP, merchandising & $\begin{array}{l}\text { Private label } \\
\text { developer/importer }\end{array}$ & Southeast \\
\hline May & Female & 24 & VP, sales & Manufacturer/importer & Northeast \\
\hline Megan & Female & 7 & $\begin{array}{l}\text { Manager, product } \\
\text { development }\end{array}$ & $\begin{array}{l}\text { Product } \\
\text { developer/importer }\end{array}$ & Midwest \\
\hline Natalie & Female & 22 & Store owner & Entrepreneur & Midwest \\
\hline Sandy & Female & 6 & Lead designer & Mass market retailer & Midwest \\
\hline Tracy & Female & 10 & Project manager & Textile service bureau & Northeast \\
\hline Travis & Male & 15 & VP, design & Specialty retailer & Northeast \\
\hline
\end{tabular}

\section{Interpretation}

\subsection{Creative thinking strategies}

This topical area sheds light on what apparel professionals considered to be creativity. Participants talked about creativity as an unconventional or different type of thinking. The three themes within this topical area illustrated that creative thinking occurred through three major 
strategies (1) viewing things from different perspectives, (2) recognising untapped opportunities and (3) looking for multiple ideas or solutions to problems and then evaluating these ideas.

\subsubsection{Different perspectives}

Each of the participants believed that the ability to see things from various perspectives was a central characteristic of the creative individual.

I think creativity is looking at something in a different way and having a different solution to it (Lana).

It's very important to take something and see it differently. That's what it [creativity] is all about (Lynn).

Professionals agreed that this skill applied to all stages and aspects of the industry, from garment creation to production and retail. May, a vice president of sales, stated: 'My definition of creativity is always looking at things in a new way, be it the garment itself, or the way to get that garment produced and delivered to the customer, or the pricing strategy for the garment'.

Participants acknowledged that the ability to perceive an issue from different points of view required a conscious intellectual effort to go beyond the first and most noticeable solution. Sandy, a lead designer for a mass-market retailer, stated the way to generate ideas was, 'Just working your mind around different kinds of problems from lots and lots of different angles'. A vice president of design for a trendy specialty retailer noted that this approach could be employed by teams, even though this complicated the process.

I think human nature is [that] you always go to the path of least resistance and, you know, take the easy way. And it's hard to stop yourself and, like: 'Wait, wait! We need to rethink.' And it's hard. It's something I always try with my team, trying to get them to think in different ways. (Travis)

There was a clear consensus among industry professionals and participants who worked in education (Kelly) and museums (Linda) that creativity was a divergent thinking process.

[Creativity is] to take new perspectives and look at different situations in a way that people have never thought about looking at something before, whether that's problem solving or a visual kind of problem. (Kelly)

I think [creativity] means having a fresh or different perspective whether it's an exhibition, or even just writing a report. (Linda) 


\subsubsection{Identifying opportunities}

Another aspect of creative thinking was a continuous search for yet unexploited prospects, which could be found at any stage of the apparel supply chain.

We're constantly thinking of things, like: 'How can we market ourselves differently than other brands? How can we ... ? What can I ... ? Can we put stuff up on the website that's going to make people want to go to the stores?' It's constant, all the time (Ella).

A vice-president of technical design and product development at a famous designer's house discussed how exploring unique combinations and non-traditional use of materials resulted in a discovery of innovative solutions. This strategy emerged as the company's competitive advantage. Emma stated, 'We push the envelope as far as trims and fabrics go and we do things that no one else wants to venture into. We really have to be creative to come up with solutions'.

Participants shared several approaches that they used to discover untapped opportunities. One tactic was paying close attention to the atmosphere of the work setting and the larger society. Lynn, a vice president of merchandising in an importing company, stated, 'Being creative, I think, is being aware of your surroundings. How am I going to maximise and use the best of my surroundings? I think that's a creative process'. The essence of another tactic was challenging traditional ways of doing things. If something has always been done one way, then doing it differently might represent an interesting prospect for creative output: '... it comes from their creativity of making a high quality, fashion-right, design-right, and source-right product without boundary. They are innovative because they're finding new ways to do things' (James). The third approach suggested capitalising on problems the company was enduring by viewing an existing problem as an opportunity. May, a high-ranking vice president with more than 20 years of experience, stated: 'I think every day it seems, like, there is a problem, or opportunity, presented to me and just to come up with a new way to get it done [is creativity]'

\subsubsection{Multiple ideas}

Participants repeatedly discussed the ability to come up with multiple ideas in response to a question or problem as an important component of creative thinking. They believed that there was no such thing as 'only one right' answer, idea, design or solution. Moreover, there was an agreement that what was a good solution yesterday might not work today, in the ever-changing, fast-paced apparel business. Ella, a designer, commented: 'You have to think of ten ways to fix a problem. To me, that's being creative, if you're saying: "Oh, well, we could do this, or we could do this, or we could this, or we could this." Tracy, a product manager, emphatically stated, 'There's no set-in-stone answer for anything we do'. It was emphasised that a creative individual was never satisfied with the 'first' answer or idea that comes to mind, which was often categorised as the most obvious and 'ready-to-go' solution. Instead, it was essential to look for other possible solutions. According to Bob, an associate designer for a specialty retailer, 'It's like 
looking at a problem and not being satisfied with it, not achieving it. And it's, like, well, what are ALL our options?'

After the generation of ideas, the selection of the 'best' idea for implementation was required. This, in turn, called for another skill of the creative person: evaluating new ideas and determining the most advantageous course of action. Lana, a chief merchandising officer stated:

You know, if you're having a fit issue, there's probably two or three different ways you might be able to fix it or think about it. And all of them might be right in certain ways, but you know what might be the most optimal in terms of the best fit, the best construction for the factory, and, you know, the least loss of time for the next fit sample.

Participants generally agreed that creativity was a way of thinking differently about all aspects of their jobs: through analysing situations, or problems, from a variety of perspectives. These industry professionals developed strategies to discover opportunities for growth and improvement in unique ways, and tried to find as many successful ideas for change as possible.

\subsection{Manifestation of creative thinking}

The second topical area outlined participant perspectives on how creativity was manifested within their companies. The first two themes showed that creativity within the apparel industry can be demonstrated as creative problem solving and/or artistic creativity. The third theme revealed that the perceptions of creative outlets within the apparel profession evolved as the participants gained more experience.

\subsubsection{Creative problem solving}

When reflecting on their experiences, all participants agreed that creativity materialised within the industry as creative problem solving. Representatives from all stages of the apparel supply chain shared this perspective. For example, Sandy, a young designer, believed that it did not matter whether a problem was design-, production- or merchandising-related because the strategies used to address it were the same. She stated, 'Creativity is really the ability to solve problems whether they are design, artistic, production, or assortment problems. It is the ability to think around those problems and come up with new ideas'. More experienced professionals, employed in the industry closer to 30 years, shared this perception of creativity as a problem-solving skill. For example, creativity played a very similar role in the daily, work-related activities for James, a creative director of a $\$ 500$ million company, 'My creativity is $100 \%$ problem solving'. Don, a vice president of sales for an importing company stressed, 'Creativity to me is creating an answer and a solution to a problem that has been drawn to your attention, that you need to address'. 
Participants not connected to the corporate world, an entrepreneurial business owner (Natalie) and a museum professional (Leigh), also viewed creativity as an ability to find unconventional solutions to problems.

I think of creativity as problem solving. (Natalie)

If you're seeing creativity as part of the problem solving, it helps to know that there are ways to do things differently. (Leigh)

\subsubsection{The duality of creativity in apparel careers}

Roughly two-thirds of participants acknowledged the duality of the phenomenon in the industry. The first type was associated with the skills of innovatively solving problems, whereas the second was related to artistic activities. Similar to the group discussed above, these professionals worked in diverse apparel-related careers. A director of product development, Kyla, and a vice president of sales, May, shared similar perspectives on how creativity is demonstrated within the industry.

It's somebody who can problem solve, who can think out of the box - to use an overused term, who can see a solution that might be on the other side of a forest. Then you have artistic creativity, which is slightly different than that - when you have the ability to develop an aesthetic that is pleasing, or different, or exciting; whatever that project is supposed to capture. (Kyla)

The most obvious [meaning] is from the design aspect: who can make a new or exciting product or something that the market has not yet seen that is attractive and inviting to everyone, whether it's through colour, print pattern, new silhouette, or new texture. Creativity is also in how to identify opportunities and problems and create a solution for them. (May)

While the participants recognised the importance of artistic creativity in the industry, they agreed that it involved only a small portion of their day-to-day responsibilities. Even professionals who worked in creative design estimated that they used artistic creativity only $10-20 \%$ of the time and relied on creative problem solving in the remainder of their job-related responsibilities. According to Lana,

Creativity is getting the product made all the way through the process versus just sitting and sketching it, or thinking of it, which is at best one-tenth of a day. So, really, it's creative problem solving. It's, like, putting a puzzle together: you have to fit all the pieces together versus just creating the sketch, which is the smallest part of the job. 
Overall, participants agreed that the ability to find creative solutions to everyday problems was more important than sheer artistic talent. Ella, a creative designer, stated problem solving or 'how you're going to organise things and handle the tasks that you have been given' was more important than artistic creativity.

\subsubsection{Evolving perception of creativity}

All participants in this study, regardless of the years of work experience, recognised the importance of creative problem solving. However, professionals with the greater amount of work experience placed more emphasis on creative problem solving skills, rather than artistic talent. Further, participants noted that their perception of creativity was not static, but evolved with career progression. They tended to share this perspective regardless of whether their careers were in design or merchandising. May stated,

When people [are] starting their careers, everybody thinks that creativity is limited only to the design aspect of the business: what is the newest, latest colour, print pattern, silhouette, details, trims, fabrics, or whatever. As you get more mature and you understand that problem solving and capitalizing on new opportunities always require a new way of thinking - thinking outside of the box or doing something differently - then you realize that creativity has a much broader definition.

Professionals in design-related careers noted that their opinion on creativity changed dramatically when they transitioned from college to industry.

When I was a student, I always stressed about that, the artistic creativity. I couldn't see the other side [of it]. I was too focused on making something new and different, that was, like, out of this world, crazy, that no one's seen before. I thought that that's what design was. And I thought that that's what being creative was. And now, being in the industry, I see the other side of the creativity, with problem solving and, you know, making a good product. (Ella)

A creative director considered that the shift from artistic to problem-solving skills might be due to evolution and changes within the apparel industry itself. According to James, a professional with 30-year experience,

When I first became a creative director and had to hire designers and graphic artists, I was always saying to myself that I needed someone who had $75 \%$ of their talent in being creative and $25 \%$ of it was in technical skills. But now - I'm not sure if it's because I've been in the industry longer or if the industry has changed - now I need someone who is 
on time, very technically established, very proficient, etc. And I really feel that this thing that we call [artistic] creativity can be the lesser of the two criteria.

\subsection{Creative outcomes}

The third topical area summarised participants' views about the outcomes of creativity. Professionals agreed that creative thinking was central in bettering any aspect of life, whether related to advancing business, career or personal life. It was emphasised that apparel companies needed to align all their creative decisions around the goal of creating value for the consumer.

\subsubsection{Advancing product and process}

Participants were in agreement that the major reason for using creativity was to improve or advance the status quo. They frequently mentioned that creative thinking was critical in accomplishing day-to-day responsibilities with greater efficiency, speed, and with fewer resources: 'Creative thinking is doing what it takes to actually make the business successful' (May).Whether a product or process, anything could become better if one approached the matter creatively. Amber, a designer, explained how technical steps of the product development could either be viewed as a routine, or as central to making the best garment possible: 'It kind of sounds boring: stitches, looking at different types of button sizes, and stuff like that. But all that stuff is critical in making the garment really beautiful and [of a high] quality level, too.'

This creative approach to daily routines ultimately helped not only the organisation, but also the creative individual who, as a result of a novel solution, simplified some aspects of the job. As stated by Ella, 'Being creative makes your job easier'. This, in turn, brings greater job satisfaction. Linda, a textile curator, mused, 'I think that if people are creative or enjoy creative aspects, I think they would enjoy the job more'. As one participant noted, the same creative thinking strategies used to improve job-related situations were applicable to one's personal life. Similar to the work environment, this required proactiveness and striving for the best outcome possible. Lana mentioned,

If something isn't going the way you wanted to in your life, you are creatively working with that and saying: 'Well, I need to change something.' And taking the action or thinking through: 'What can I do to change what I'm unhappy with, or get to where I want to go?' You know, creatively thinking about your life versus letting your life happen and wondering why you didn't get where you wanted to be.

The interview data indicated that a truly creative person did not wait for a problem to arise but rather searched for unrecognised opportunities to advance a situation. It appears that creative individuals do not follow the conventional wisdom, 'If it ain't broke, don't fix it'. They seemed to be the ones who constantly looked for ways to make the world around them a better 
place, in any sense possible. As stated by Alice: 'Being creative is looking at the current situation, weighing all of the options, and then trying to sit back and say to myself: "What can I do to make the situation better?"

\subsubsection{Value for the consumer}

Participants believed that creative ideas must be directed towards a specified goal. In the case of the apparel industry, this centre of focus was usually the ultimate consumer. Consumer needs and desires channelled employee's creativity into developing products and processes that would be appreciated by the end user. According to Tracy, her own preferences for a particular style such as 'I want to do these beautiful stripes!' were subjugated by the need to create goods that the customer would like and ultimately buy. Participants concurred that the ultimate purpose of creativity in the apparel business was value creation for the consumer. A garment might be produced very creatively, with a new look or a new feature, but unless consumers purchased it, the creativity was for naught.

It's beautiful. Love it. I personally like it, but our customer won't buy it. So, no, I don't like that. I've been in this business long enough to know that I have to understand my end result, my customer. I have to understand who the end user is that we are trying to sell to, and then build product around that (Don).

Consumer-driven creativity held true even in non-profit organisations, such as museums. Linda, a textile curator, stated, 'I think creativity for a museum job means appealing to everyone and, certainly to more people, new audiences with a fresh approach; maybe more visually appealing.'

It is clear that in the apparel industry, creativity is limited by market demand and sale-ability of the product. Yet, garments have to be exciting and different enough from other companies' offerings to compete in the marketplace and warrant consumer attention. Products must be novel, yet they cannot be too innovative to alienate a mainstream target audience. Ella, a young designer, working for a fast growing, dynamic company on the West coast explained,

To keep ahead in our market, you definitely have to be creative and come up with a new product that other people aren't offering. But it's also making things that will sell. I hear that feedback a lot, from a lot of people. Creativity only goes to a point. You can be creative, but you still have to make a product that's going to sell, and that's the most important thing.

Echoing this idea, Travis a designer working for a high-end specialty retailer noted that this balancing act represented a significant challenge - to be creative yet customer-focused. He 
stated, 'It's really hard because part of what you have to do is to be very focused on your customer. And at the same time you have to be creative'.

\section{Discussion and conclusion}

By offering rich accounts of 28 professionals, this study presented an in-depth investigation of creativity in the apparel domain. The three topical areas that emerged as a result of the interviews' analyses allowed for mapping the creativity phenomenon to facilitate its deeper understanding. The mapping process resulted in a framework that illustrates and helps to explain apparel professionals' perspectives on creativity in the workplace (Figure 1). Each of the three shaded rounded rectangles represents one of the three topical areas (from left to right): creative thinking strategies, manifestation of creative thinking, and creative outcomes. Small rectangles located inside of the large shaded rectangles correspond to the themes within each topical area. Block arrows that connect the large shaded rectangles symbolise relationships between the topical areas.

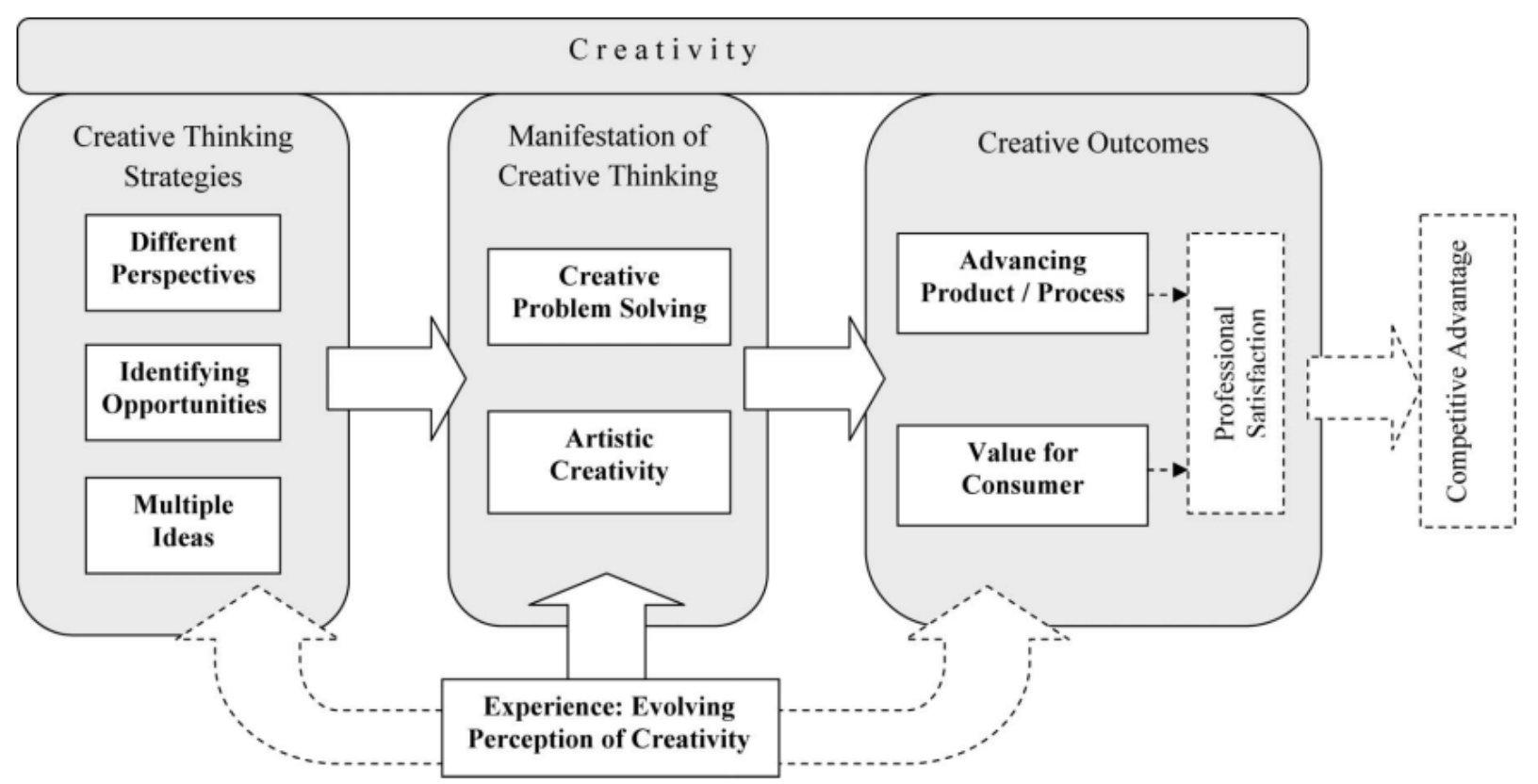

Figure 1. Mapping the creativity phenomenon in apparel profession. Solid arrows and lines illustrate relationships/constructs derived from the data; dashed arrows and lines illustrated hypothesised relationships/constructs.

The rationale for the relationships between the topical areas and themes was as follows. The first topical area represented strategies used by apparel professionals as basic tools for thinking creatively. When one uses these fundamental strategies, he or she engages in a creative thinking process and, as a result, can innovatively solve problems or come up with unique and novel artistic ideas. The process of utilising creative thinking strategies is often hidden from 
observers, who can only see that a problem is being solved in an unconventional way or an original design idea is being developed. This is what the second topical area describes, the manifestation or demonstration of creative thinking through the solving of a problem or creation of a new idea, process or product. Therefore, the first topical area captured the fundamental building blocks of creative thinking, and the second described the ways in which creative thinking is manifested or materialised in the context of apparel profession. The third topical area represented the outcomes of creative problem solving.

The first topical area, creative thinking strategies, summarised participants' views on what the fundamental building blocks of creativity were (Figure 1). Professionals, who held various positions in apparel related enterprises, viewed creativity as unconventional thinking. Participants indicated the creative thinking occurred through (1) viewing things from diverse perspectives, (2) identifying opportunities and (3) going beyond the first and most obvious answer and considering multiple solutions and ideas. This finding supports the conceptualisation of creativity as a dynamic process of divergent thinking wherein problems are identified, multiple ideas are generated and productive solutions may be implemented (e.g. Basadur 1994, Mumford 2003). Similarly, Guilford (1950), a renowned creativity expert, linked the creativity phenomenon to divergent thinking, or the ability to develop unique ideas and envision multiple solutions. There is no agreement among scholars whether and how the creative thinking process is different from the non-creative thinking process (see Lubart 2001 for discussion). In our study, apparel professionals viewed creative thinking as a special, or different type of thinking that was not the same as 'conventional' thinking. Further investigation of this topic is warranted.

Vincent et al. (2002) empirically confirmed that 'divergent thinking exerted unique effects on creative problem solving' (p. 163). This supports our conceptualisation of the relationship between the first topical area, creative thinking strategies, and the second topical area, manifestation of creative thinking (Figure 1). Regardless of the primary focus of their jobs, from creative design to sales to museums, all participants emphasised the critical role of creative problem solving in effectively completing their everyday responsibilities, furthering their careers and contributing to the success of their organisations. In contrast, artistic creativity was not mentioned by all participants in the course of the interviews. Participants in this study perceived creativity, not in terms of significant breakthroughs producing innovation, but rather relatively small creative improvements to everyday processes or development of products. This could be due to the nature of the fashion industry in which the concept of copying or 'knocking-off' another designer's idea is an accepted and even institutionalised practice, and patent and copyright laws rarely apply to ready-to-wear apparel (Marcketti and Parsons 2006).

The lesser importance placed by participants on artistic creativity (in comparison with the creative problem solving) might be because none of them were involved in 'purely artistic' activities. In our study, all participants, including creative designers who worked for design houses, were part of the ready-to-wear business that produced garments for the mass consumer. When defining the creator as the producer of the aesthetic object, Fiore et al. (1996) excluded mass-produced design. Gluck et al. (2002) found that 'free artists' (painters and sculptors) 
defined creativity somewhat differently than 'constrained artists' (architects and designers). The former group stressed imagination, talent, risk-taking and hard work as central to creativity. Constrained artists placed greater importance on problem solving and 'the value that creative work has for others and for society in general' (p. 64). Both groups, however, agreed that creative people should have many ideas.

Professionals in the study experienced an evolution in viewing creativity as simply an artistic process of crafting new designs to a broader and more inclusive concept as they gained more work experiences. This broader perspective of creativity encompassed artistic creations, as well as creative problem solving. In the framework, this finding is illustrated with the theme, experience: evolving perception of creativity. This result is supported by Albert's argument (1990) that creativity is emergent along with individual maturation and learning experiences. Even though there was little evidence in the data about the influence of professional experience on the use of creative thinking strategies and creative outcomes, the authors hypothesised these relationships.

Apparel professionals agreed that they used creativity to generate value through improving a product or process as illustrated by the third topical area creative outcomes. The ultimate goal was to create apparel to meet consumer desire and demand. This finding is supported by Gluck et al.'s (2002) findings that designers and architects viewed the value of the final products as the driving force behind the creative process. Even though some of the participants verbalised that generating creative outcomes resulted in professional satisfaction, this was not a frequent statement. However, the professionals interviewed conveyed a great deal of enthusiasm, passion, and excitement when discussing creativity. This indicates that being able to realise creativity through improving a product or process and/or creating value for consumer may lead to professional satisfaction. Although participants did not directly discuss how employee creativity built competitive advantage for a company, there is agreement among experts that this is the case across diverse industries (DiLiello and Houghton 2006).

This research contributes to the body of literature that describes and defines creativity in the workplace. Despite the fact that a number of creativity models and theories have been proposed, 'no structural framework of conceptions of creativity has been achieved' (Gluck et al. 2002, p. 56). Even though scholars have long associated creativity with ideation fluency (Basadur 1994, Mumford 2003), discovery of problems or opportunities (Csikszentmihalyi 1990, Mumford 2003), ability to see problems in new ways (Milgram 1990, Sternberg 2006), problem solving process (Milgram 1990), artistic performance (Csikszentmihalyi 1990, Gluck et al. 2002) and creative outcomes (Amabile 1983, Harrington 1990), the proposed framework is the first attempt to understand the relationships among these constructs.

Based on industry insiders' perspectives, the study provided valuable insights into creativity applications within the apparel profession. The findings might be of interest to industry practitioners who want to foster creative environments within their companies. The ability to think creatively is one of the few sustainable competitive advantages in today's marketplace. As a result, competitive companies can contribute to a greater comparative advantage of the US 
industry on the global scale. Specifically, in-depth description of how professionals used creative strategies for problem-solving as well as artistic creativity might be emulated and practiced when dealing with non-trivial problems and developing innovative solutions, ideas and products. Understanding how creativity perspectives evolve with increased years of experience in the industry might help ease the transition of creative individuals from college to work environments. Focusing on important creative outcomes might help channel creative forces within a company to ultimately increase its competitive advantage and profitability.

The framework may be used as a guideline for developing and fostering creative problem-solving skills in apparel students to better prepare them for careers within the global industry. Educators could integrate creative problem solving as part of curricula and emphasise its importance for all stages of apparel product development, manufacturing, distribution, marketing and sales. Implications of this study go beyond the apparel domain, as a recent survey found that $57 \%$ of employers think half or fewer college graduates have the skills such as self-direction and problem solving crucial to advance in the workplace (Anon 2008).

The apparel creativity framework opens up new venues for future research. First, the framework might be tested, refined and extended using a quantitative research design. This would be particularly important in the development of a domain-specific creativity assessment that may be useful in determining an individual's potential for work in the apparel industry. Second, the framework might be relevant to other industries, particularly, those that involve aspects of designing products for consumers. The transferability of the framework can be explored. Third, apparel professionals in other countries may view creativity differently, depending on what competitive advantages national industries might have. For example, Italian or French professionals may place a greater importance on artistic creativity in comparison with the representatives of the US apparel industry, known for sport and casual mass market brands with the goal of delivering value to consumers.

\section{References}

Albert, R.S., 1990. Identity, experiences, and career choices among the exceptionally gifted and eminent. In. In: M.A. Runco and R.S. Albert, eds. Theories of creativity. Newbury Park, CA: Sage, 190-212.

Amabile, T.M., 1983. The social psychology of creativity: a componential conceptualization. Journal of Personality and Social Psychology, 45, 357-376.

Anon, 2008. Colleges need to improve, say employers; employers say graduates come to them lacking in global knowledge, self-direction, writing and critical thinking, and colleges need to get more creative about how they test [online]. WFC Resources Newsbrief. Available from: http://galenet.galegroup.com [Accessed 9 September 2009].

Basadur, M.S., 1994. Managing the creative process in organizations. In: M.A. Runco, ed. Problem finding, problem solving, and creativity. Norwood, NJ: Ablex, 237-268. 
Busse, T.V. and Mansfield, R.S., 1980. Theories of the creative process: a review and a perspective. Journal of Creative Behavior, 14 (2), 91-103.

Cerny, C.A., Eicher, J.B., and DeLong, M.R., 1993. Quilt making and the modern guild: a cultural idiom. Clothing and Textiles Research Journal, 129 (1), 16-25.

Csikszentmihalyi, M., 1990. The domain of creativity. In: M.A. Runco and R.S. Albert, eds. Theories of creativity. Newbury Park, CA: Sage, 190-212.

Danielson, D.R., 1986. According to the artists: professional fashion illustrators' views about their art form. Clothing and Textiles Research Journal, 5 (1), 27-33.

DiLiello, T.C. and Houghton, J.D., 2006. Maximizing organizational leadership capacity for the future: toward a model of self-leadership, innovation, and creativity. Journal of Managerial Psychology, 21 (4), 319-337.

Dudek, S. and Co^te', R., 1994. Problem finding revisited. In: M.A. Runco, ed. Problem finding, problem solving, and creativity. Norwood, NJ: Ablex, 130-150.

Esterberg, K.G., 2002. Qualitative methods in social research. Boston, MA: McGraw-Hill.

Fiore, A.M., 2008. The digital consumer: valuable partner for product development and production. Clothing and Textiles Research Journal, 26 (2), 177-190.

Fiore, A.M., Kimle, P.A., and Moreno, J.M., 1996. Aesthetics: a comparison of the state of the art outside and inside the field of textiles and clothing. Part 1: creator and creative process. Clothing and Textiles Research Journal, 14 (1), 30-40.

Florida, R., 2002. The rise of the creative class. New York: Basics Books.

Ford, C. and Gioia, D., 2000. Factors influencing creativity in the domain of managerial decision making. Journal of Management, 26 (4), 705-732.

Furnham, A. and Bachtiar, V., 2008. Personality and intelligence as predictors of creativity. Personality and Individual Differences, 45, 613-617.

Gluck, J., Ernst, R., and Unger, F., 2002. How creatives define creativity: definitions reflect different types of creativity. Creativity Research Journal, 14 (1), 55-67.

Goswami, A., 1996. Creativity and the quantum: a unified theory of creativity. Creativity Research Journal, 9 (1), 47-61.

Guilford, J.P., 1950. Creativity. American Psychologist, 5, 444-454.

Gumusluoglu, L. and Ilsev, A., 2009. Transformational leadership, creativity, and organizational innovation. Journal of Business Research, 62, 461-473.

Harrington, D.M., 1990. The ecology of human creativity: a psychological perspective. In: M.A. Runco and R.S. Albert, eds. Theories of creativity. Newbury Park, CA: Sage, 143-169.

Kaufman, J.C. and Beghetto, R.A., 2008. Beyond big and little: the four C model of creativity. Review of General Psychology, 13 (1), 1-12.

Kvale, S., 1996. Inter-views. Thousand Oaks, CA: Sage.

Lubart, I.T., 2001. Models of the creative process, past, present and future. Creativity Research Journal, 13 (3), 295-308.

Malem, W., 2008. Fashion designers as business. Journal of Fashion Marketing and Management, 12 (3), 398-414. 
Marcketti, S.B. and Parsons, J.L., 2006. Design piracy and self regulation: the Fashion Originators' Guild of America: 1932-1941. Clothing and Textiles Research Journal, 24 (3), 214-228.

McCracken, G., 1988. Culture and consumption. Bloomington, IN: IndianaUniversityPress.

Milgram, R.M., 1990. Creativity: an idea whose time has come and gone? In: M.A. Runco and R.S. Albert, eds. Theories of creativity. Newbury Park, CA: Sage, 215-233.

Mumford, M.D., 2003. Where have we been, where are we going? Taking stock in creativity research. Creativity Research Journal, 15 (2), 107-120.

Mumford, M.D. and Gustafson, S.B., 1988. Creativity syndrome: integration, application, and innovation. Psychological Bulletin, 103, 27-43.

Mumford, M.D., et al., 2010. Cross-field differences in creative problem-solving skills. Creativity Research Journal, 22 (1), 14-26.

Nemiro, J., 1997. Interpretive artists: a qualitative exploration of the creative process actors. Creativity Research Journal, 10, 229-239.

Ochse, R., 1990. Before the gates of excellence: the determinants of creative genius. New York, Cambridge University Press.

Pedersen, E.L. and Burton, K.L., 2009. A concept analysis of creativity: uses of creativity in selected design journals. Journal of Interior Design, 35 (1), 15-32.

Runco, M.A., 2004. Creativity. Annual Review of Psychology, 55, 657-687.

Sapp, D.D., 1995. Creative problem-solving in art: a model for idea inception and image development. Journal of Creative Behavior, 29, 173-185.

Shalley, C.E., Gilson, L.L., and Blum, T.C., 2000. Matching creativity requirements and the work environment: effects on satisfaction and intentions to leave. Academy of Management Journal, 46 (2), 215-223.

Speer, J., 2008. Call for creativity, new thinking a difficult economic climate[online]. Apparel Magazine. Available from: http://www.apparelmag.com [Accessed 18 March 2010].

Spiggle, S., 1994. Analysis and interpretation of qualitative data in consumer research. Journal of Consumer Research, 21, 491-503.

Sternberg, J.R., 2006. The nature of creativity. Creativity Research Journal, 18 (1), 87-98.

Sternberg, R.J. and Lubart, T.I., 1999. The concept of creativity: prospects and paradigms. In. In: J.R. Sternberg, ed. Handbook of creativity. New York: Cambridge University Press.

van Manen, M., 1990. Researching lived experience:. Human science for an action sensitive pedagogy. New York, State University of New York Press.

Vincent, A.S., Decker, B.P., and Mumford, M.D., 2002. Divergent thinking, intelligence, and expertise: a test of alternative models. Creativity Research Journal, 114 (2), 163-178.

Warr, A., and O'Neill, E., 2005. Understanding design as a social creative process. In: Creativity and cognition proceedings of the 5 th conference on creativity \& cognition, 118-127. 